\title{
ANALISIS IMPLEMENTASI KEBIJAKAN PEMBELAJARAN JARAK JAUH PADA MASA PANDEMI COVID-I 9 DI KOTA DENPASAR
}

\author{
ANALYSIS OF THE IMPLEMENTATION OF DISTANCE LEARNING \\ POLICIES DURING THE COVID-I 9 PANDEMIC IN THE CITY OF DENPASAR
}

\author{
Ni Komang \\ Yulia \\ Narmaningsih ${ }^{*}$ \\ I Nyoman \\ Sunarta ${ }^{2}$ \\ * 1,2 Universitas Pendidikan \\ Nasional,
}

email:

'yuliaanarma@gmail.com

2Sunarta2000@yahoo.com

\section{Kata Kunci:}

Pembelajaran Jarak Jauh

Pendidikan

Covid-19

Keywords:

Distance Learning

Education

Covid-19

\section{Accepted}

June 2021

\section{Published}

October 2021

\begin{abstract}
Abstrak
Proses pembelajaran di sekolah pada masa pandemi Covid-19 mempunyai banyak permasalahan yang dihadapi. Pandemi Covid-19 yang melanda dunia termasuk Indonesia mengharuskan mengambil sikap dalam mencegah penularan yang lebih luas, termasuk sektor pendidikan.Berdasarkan Surat Edaran Menteri Pendidikan dan Kebudayaan Nomor 4 Tahun 2020 tentang Pelaksanaan Kebijakan Pendidikan Dalam Masa Darurat Penyebaran Corona Virus Disease (COVID-19) dan Surat Edaran Sekretaris Daerah Provinsi Bali Nomor 5I/SatgasCovid I9/III/2020 tentang Pelaksanaan Kebijakan Pendidikan Dalam Masa Darurat Penyebaran Corona Virus Disease (COVID-19) di Provinsi Bali kepada seluruh Satuan Pendidikan di Provinsi Bali. Penelitian ini mengkaji pelaksanaan kebijakan pendidikan dalam masa pandemi Covid-19 berkaitan dengan kebijakan pembelajaran jarak jauh. Tujuan penelitian ini untuk menggambarkan secara nyata motivasi belajar para pelajar dalam pembelajaran selama masa pandemi Covid-19, dengan harapan penelitian ini menjadi bahan evaluasi bagi pemegang kebijakan instansi pendidikan dalam menciptakan pembelajaran daring yang lebih efektif guna meningkatkan motivasi belajar. Penelitian ini menggunakan metode survey untuk membuat generalisasi dari sebuah pengamatan dan hasilnya akan lebih akurat dimana data diambil dalam kondisi yang tidak terkontrol/alamiah namun ada perlakuan dalam pengumpulan data yakni dengan menyebar kuesioner. Hasil penelitian ini membuktikan bahwa pembelajaran jarak jauh (PJJ) di masa pandemi covid-19 ini menimbulkan berbagai tanggapan dan perubahan pada sistem belajar yang dapat mempengaruhi proses pemebelajaran.
\end{abstract}




\section{PENDAHULUAN}

Saat ini pandemi virus corona atau Covid 19 sedang melanda negara-negara di dunia termasuk Indonesia. Bahkan hingga saat ini, Indonesia masih menjadi salah satu dari 20 negara yang paling terdampak Covid 19. Tentunya berbagai upaya telah dilakukan oleh pemerintah, seperti dengan mengeluarkan peraturan dan pengaturan teknis untuk berbagai kegiatan yang dilakukan oleh masyarakat. Pandemi Covid-19 yang melanda Indonesia telah berdampak pada semua aspek kehidupan, salah satunya adalah Pendidikan. Oleh karena itu, lembaga pendidikan mensyaratkan agar proses kegiatan pembelajaran dapat dilakukan dari jarak jauh, yaitu pembelajaran siswa dan guru mengajar harus tetap berjalan, meskipun siswa berada di rumah(Kemendikbud, 20I3). Oleh karena itu, pendidik perlu menggunakan media daring (online) untuk merancang pembelajaran. Berdasarkan Surat Edaran Menteri Pendidikan dan Kebudayaan Nomor 4 Tahun 2020 tentang Pelaksanaan Kebijakan Pendidikan Dalam Masa Darurat Penyebaran Corona Virus Disease (COVID-19) dan Surat Edaran Sekretaris Daerah Provinsi Bali Nomor 5I/SatgasCovid I9/III/2020 tentang Pelaksanaan Kebijakan Pendidikan Dalam Masa Darurat Penyebaran Corona Virus Disease (COVID-19) di Provinsi Bali kepada seluruh Satuan Pendidikan di Provinsi Bali. Pelaksanaan Kebijakan Pendidikan dalam Masa Darurat Penyebaran Covid19. Berbagai inisiatif dilakukan untuk memastikan kegiatan belajar tetap berlangsung meskipun tidak adanya sesi tatap muka langsung. Teknologi, lebih spesifiknya internet, ponsel pintar, dan laptop sekarang digunakan secara luas untuk mendukung pembelajaran jarak jauh.

Pembelajaran jarak jauh telah menjadi tantangan dalam dunia pendidikan. Aspek penting dari keterampilan pembelajaran jarak jauh harus ditingkatkan, termasuk melatih guru untuk menggunakan teknologi informasi dan komunikasi (Azzahra, 2020). Untuk dapat menyelenggarakan pembelajaran jarak jauh dengan lancar, guru tidak cukup hanya memiliki keterampilan teknis dasar (seperti menggunakan komputer dan menghubungkan ke Internet), mereka juga perlu memiliki pengetahuan tentang penggunaan peralatan dan perangkat lunak perekaman, serta metode pengajaran ketika tidak ada situasi. Interaksi tatap muka (video pembelajaran yang menyenangkan). Keterampilan ini diperlukan saat menggunakan platform pembelajaran online. Lebih penting lagi, kesenjangan antara skenario pelatihan dan eksekusi di tempat perlu diminimalkan (Azzahra, 2020).

Studi ini dilakukan di Dinas Pendidikan Kepemudaan dan Olahraga Kota Denpasar. Disdikpora Kota Denpasar menyatakan kesiapannya dalam menerapkan Pembelajaran Jarak Jauh (PJJ) di tengah pandemi Covid-19. Kesiapan Bali tersebut berlandaskan pada kehadiran Portal Rumah Belajar Kelas Maya Jejak Bali yang sudah ada sejak dua tahun silam. Jejak Bali (Jejaring Jelajah Kreativitas Bali) adalah Portal Learning Management System (LMS) yang didesain khusus oleh Pusat Teknologi Informasi dan Komunikasi Pendidikan dan Kebudayaan (Pustekkom) dalam mengelola kegiatan pembelajaran berbasis elektronik(e-learning). Pemerintah Kota Denpasar juga telah berusaha menyiapkan sarana dan prasarana untuk menunjang pembelajaran tersebut. Namun, perlu diakui bahwa semua ini tidak mungkin didapatkan dengan instan tetapi perlu ada kesepahaman dan duduk bersama antara guru, siswa dan orang tua. Perubahan besar yang begitu cepat ini harus dapat ditangkap oleh seorang guru untuk dapat mengembangkan metode pembelajarannya tersebut menjadi 
konten yang lebih menarik, kreatif, inovatif dan dapat menstimulus siswa didiknya untuk lebih kritis, mampu berdiskusi interaktif dengan mengacu kepada konten materi sesuai dengan rencana awal pembelajaran. Demikian halnya siswa yang baik tentu banyak mengadopsi perubahan besar yang terjadi selama ini. Berdasarkan data pendidikan di lapangan diperoleh bahwa jumlah siswa sesuai jenjang pendidikan yang berada di Kota Denpasar, terdiri dari:

Table I Data Jumlah Siswa Berdasarkan Jenjang Pendidikan di Kota Denpasar, 20I7/20I8

\begin{tabular}{|c|l|c|}
\hline Pendidikan & \multicolumn{1}{|c|}{$\mathbf{L}$} & $\mathbf{P}$ \\
\hline SD & 32.277 & 30.050 \\
\hline SMP & 17.673 & 16.558 \\
\hline SMA/SMK & 18.418 & 17.235 \\
\hline
\end{tabular}

Sumber : Dinas Pendidikan Kepemudaan dan

Olahraga Kota Denpasar, 2018

'Tabel I di atas menunjukkan bahwa tahun 2017/2018 secara keseluruhan jumlah siswa pada pada semua jenjang pendidikan di Kota Denpasar sebanyak I32.2II orang. Berdasarkan jenis kelamin, tampak jumlah siswa laki-laki jauh lebih tinggi daripada perempuan.

\section{METODOLOGI PENELITIAN}

Penelitian ini menggunakan metode survey untuk membuat generalisasi dari sebuah pengamatan dan hasilnya akan lebih akurat dimana data diambil dalam kondisi yang tidak terkontrol/alamiah namun ada perlakuan dalam pengumpulan data yakni dengan menyebar kuesioner. Hasil penelitian ini membuktikan bahwa pembelajaran jarak jauh (PJJ) di masa pandemi covid-19 ini menimbulkan berbagai tanggapan dan perubahan pada sistem belajar yang dapat mempengaruhi proses pemebelajaran.

\section{HASIL DAN PEMBAHASAN}

Secara legal formal, berdasarkan Peraturan Menteri Pendidikan dan Kebudayaan Nomer 109/20I3 Pasal 2, menyebutkan bahwa tujuan PJJ adalah untuk memberikan layanan pendidikan tinggi kepada kelompok masyarakat yang tidak dapat mengikuti pendidikan secara tatap muka, dan memperluas akses serta mempermudah layanan pendidikan tinggi dalam pembelajaran. Dengan begitu dapat diartikan bahwa PJJ adalah suatu sistem pendidikan yang memiliki karakteristik terbuka, belajar mandiri, belajar tuntas dengan memanfaatkan Teknologi, Informasi dan Komunikasi (TIK) dan/atau menggunakan teknologi lainnya, dan/atau berbentuk pembelajaran terpadu perguruan tinggi.

Berdasarkan survey yang dilakukan kepada pelajar di Kota Denpasar Bali sebanyak 50 pelajar terdiri dari 15 perempuan dan 35 laki-laki. Adapun data sebaran respondennya tampak sebagai berikut:

Gambar I Jumlah respon siswa melalui kuisioner sesuai jenjang pendidikan di Kota Denpasar

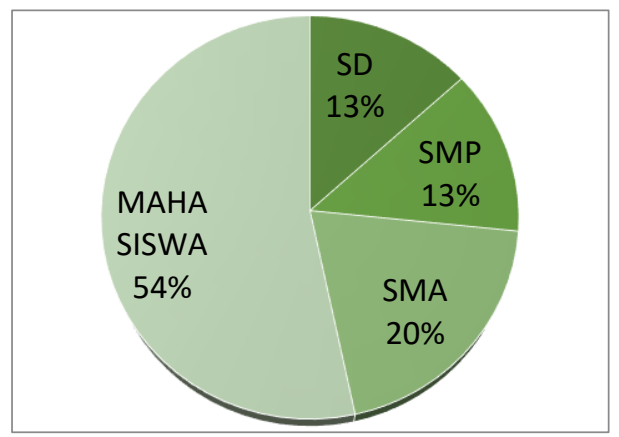

Sumber: Hasil Kuisioner Melalui Google Form

Gambar I dapat diketahui bahwa jumlah mahasiswa yang mengisi e-kuesioner paling banyak memberikan tanggapan 54 persen, urutan selanjutnya adalah pelajar sebesar 20 pesen dan urutan terakhir adalah pelajar SD dan SMP sebesar 13 persen. Adapun persentase hambatan motivasi belajar siswa/mahasiswa dari rumah selama masa pandemi Covid- 9 dapat dilihat ke dalam grafik. 
Gambar 2 Persentase hambatan belajar yang terjadi adanya kebijakan pembelajaran jarak jauh

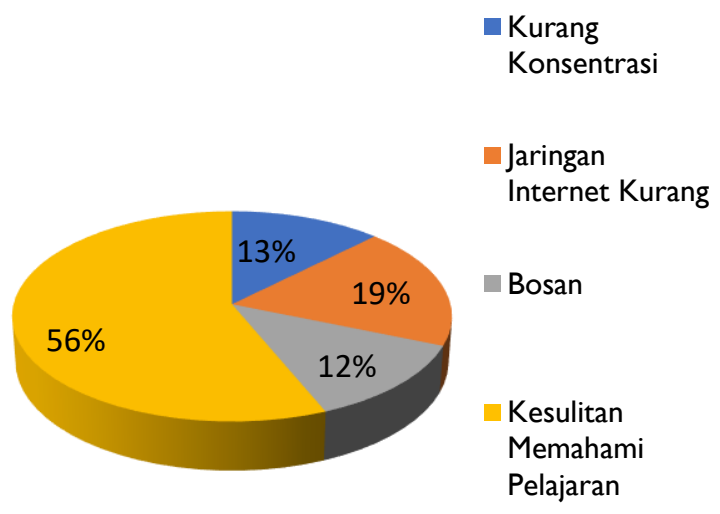

Sumber: Hasil Kuisioner Melalui Google Form

Gambar 2 menunjukkan hambatan belajar dari rumah selama masa Pandemi Covid-19 diperoleh ratarata sebesar 56 persen berada pada klasifikasi cukup tinggi. Hal ini menunjukan pandemi Covid-19 melanda dan mempengaruhi berbagai sektor kehidupan, khususnya cara belajar mahasiswa secara tiba-tiba berubah dari tatap muka di kampus/ sekolah menjadi pembelajaran jarak jauh (belajar dari rumah) membuat motivasi belajar siswa/mahasiswa turun atau bahkan merosot tajam karena kesulitan untuk konsentrasi dalam pelajaran. Pelajar di Kota Denpasar Bali saat ini mampu dengan cepat beradaptasi dengan perubahan pola belajar, angka persentase ini juga menunjukkan Denpasar Bali cukup siap dalam menghadapi era pembelajaran 4.0 karena angka persentase kekurangan jaringan internet cukup rendah seperti tampak pada grafik.
Gambar 3 Pernyataan siswa tentang efektifitas implementasi pembelajaran jarak jauh

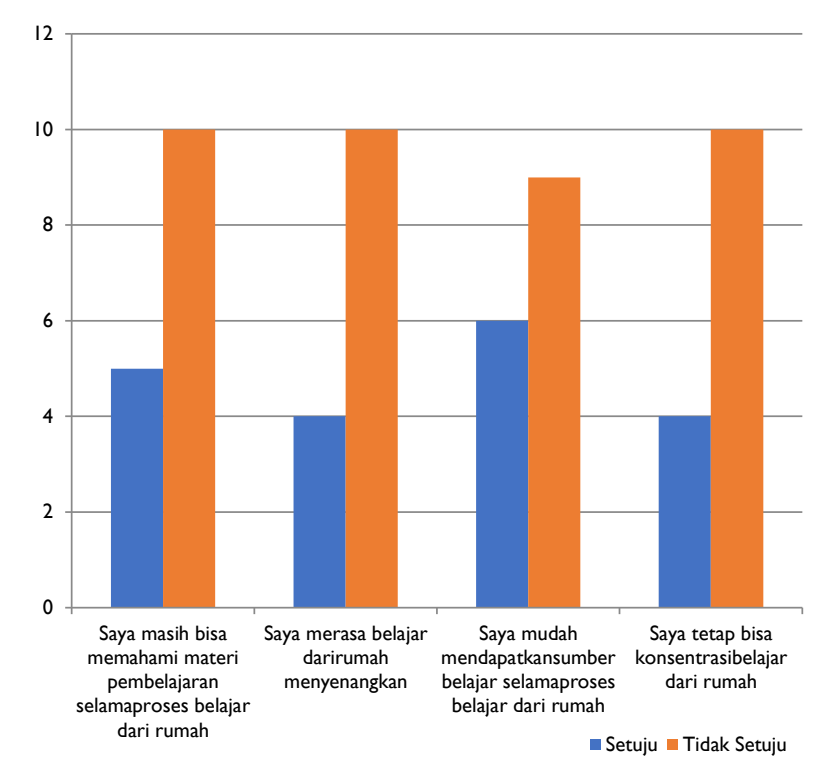

Sumber: Hasil Kuisioner Melalui Google Form

Gambar 3 menunjukkan bahwa pernyataan mengenai respon pelajar tentang efektifitas adanya implementasi kebijakan pembelajaran jarak jauh di Kota Denpasar. Tingginya angka yang menyatakan tidak setuju dalam pernyataan diatas, dengan jawaban pernyataan bahwa masih banyak pelajar yang kurang maksimal dalam memahami materi pelajaran yang diberikan, menyatakan tidak setuju bahwa belajar dari rumah menyenangkan, tidak setuju bahwa mudah mendapatkan sumber belajar dari rumah, dan tidak setuju dengan pernyataan jika belajar dari rumah bisa lebih berkonsentrasi. Sukses dan tidaknya pembelajaran sebagian besar ditentukan oleh motivasi peserta didik. Motivasi adalah sesuatu yang menggerakkan atau yang mendorong peserta didik untuk belajar, dengan motivasi yang tinggi, peserta 
didik akan berupaya dengan sekuat tenaga untuk menempuh berbagai strategi yang positif dalam mencapai keberhasilan belajar.Motivasi besar pengaruhnya dalam diri seseorang terkait apa yang dipelajari, bagaimana cara belajar dan kapan memilih untuk belajar.

\section{KESIMPULAN}

Proses pembelajaran jarak jauh yang dilaksanakan saat ini belum dapat disebut sebagai kondisi belajar yang ideal, melainkan kondisi darurat yang harus dilaksanakan. Masih terdapat berbagai kendala sehingga semua pembelajaran dapat optimal. Pemerintah telah mendukung dan memfasilitasi pelaksanaan pembelajaran daring lebih luas, bekerja sama dengan Kominfo dan provider layanan telekomunikasi. Berkat upaya tersebut masyarakat dapat mengakses beragam konten belajar jarak jauh melalui berbagai platform seperti Rumah Belajar, Kelas Pintar, Quipper School, Ruang Guru, dan Zenius untuk jenjang PAUD dan Dikdasmen. Sebagai bentuk dukungan, Pemerintah mendorong prioritas Rumah Belajar untuk dapat bekerja sama dengan Lembaga Penyiaran Publik (LPP) TVRI dan RRI agar sistem pembelajaran berbasis IT ini bisa dimanfaatkan saat kendala di jaringan internet. Beberapa upaya tersebut dilakukan untuk mempersiapkan agar PJJ dapat terlaksana secara optimal, bukan hanya dalam situasi pandemi saja, tetapi juga untuk peningkatan kualitas pendidikan di tengah pesatnya perkembangan teknologi.

\section{UCAPAN TERIMA KASIH}

Penulis mengucapkan terima kasih kepada tim peneliti yang telah banyak membantu sehingga penelitian ini selesai dengan baik. Kepada Dr. I Nyoman Sunarta dan LP2M Universitas Pendidikan Nasioanl Denpasar selalu suport kepada kami untuk tetap produktif dibidang penelitian dan publikasi.

\section{REFERENSI}

Ahmad Faizin dan David Efendi, Membaca Korona: Esaiesai Tentang Manusia, Wabah, Dan Dunia, 2020, Gresik: Caremedia Communication, h. 50-52.

Arifa, F.N. (2020). Tantangan Pelaksanaan Kebijakan Belajar Dari Rumah Dalam Masa Darurat Covid19. Info Singkat, XII, No. 7///Puslit/April/2020.

Azzahra, N.F. (2020). Mengkaji Hambatan Pembelajaran Jarak Jauh di Indonesia di Masa Pandemi Covid19. Jakarta: Center for Indonesian Policy Studies (CIPS).

Jaelani, A., dkk. (2020). Penggunaan Media Online Dalam Proses Kegiatan Belajar Mengajar PAI Dimasa Pandemi Covid-19 (Studi Pustaka Dan Observasi Online). Jurnal IKA, Vol. 8 No. I, Juni 2020

Kusnandar, I. (20I2). Analisis Kebijakan Publik. Multazam.

L, IDRUS, 'Evaluasi Dalam Proses Pembelajaran', Adaara: Jurnal Manajemen Pendidikan Islam, 9.2 (2019), 920-35 https://doi.org/10.35673/ajmpi.v9i2.427

Majid, Abd, Analisis Kebijakan Pendidikan, ed. by Alviana Cahyanti, Ist edn (Yogyakarta: Penerbit Samudra Biru, 2018) www.samudrabiru.co.id 
Munir. (2009). Pembelajaran Jarak Jauh Berbasis Teknologi Informasi dan komunikasi. Bandung: Alfabeta.

Munadi Y. (2010). Media Pembelajaran (Sebuah Pendekatan Baru). Jakarta: Gaung Persada Press.

Saleh, AM. (2020). Problematika Kebijakan Pendidikan di tengah Pandemi dan dampaknya terhadap proses pembelajaran di Indonesia. Makassar : Universitas Islam Negeri Makassar

Subarsono, A. G. (2005). Analisis Kebijakan Publik Konsep, Teori dan Aplikasi. Pustaka Pelajar. 